\title{
Statistical Analysis of the Core Determinants Influencing the Consumers Brand Preference in Generalization of Bath Soaps
}

\section{Jakkireddy Suresh Reddy*, Ramana KA and Mehul Bhandari}

Department of Management Studies, Rajeev Gandhi Memorial College of Engineering and Technology, Jawaharlal Nehru Technological University Anantapur, Andhra Pradesh State, India

\begin{abstract}
The necessity of this study is to identify and analyze the determinants affecting consumer's preference of bath soaps. Among the factors education, age, income, price, advertisement, celebrity, quality, the factors education, income and product qualities are affecting consumer's brand preference of bath soaps. With one way ANOVA it had been found that the income factor is influencing the consumer's brand preference in which the calculated F-Value (2.66522)>F-Critical value (2.24640). With Two way ANOVA without replication it has been found that education factor influence the brand preference, where the calculated value for education, F-Value (3.7956)>F-Critical value ( 3.0069). The calculated F-Value for age factor, F-Value (1.4301)<F-Critical value (3.0069) and therefore the age factor doesn't influence the brand preference. The simple regression analysis between price and brand preference shows that there is weak relationship between price and brand preference. The correlation coefficient is 0.28 . With multiple regression analysis it has been found that the two independent variables didn't add statistically significantly prediction for brand preference. The Z-test concludes that the product quality influences the brand preference. Consumers are more conscious product quality in brand preference. The marketers should look at target market consumer profile especially the education factor, income factor at the time of designing the commercials.
\end{abstract}

Keywords: Consumer brand preference; ANOVA without replication; Regression analysis; Explanatory factor analysis

\section{Introduction}

Soap is a product that many people take for granted but some prefer the brands based on some factors at which the marketer need to look at.

India is a vast country with a population of 1,039 million people. The household of penetration of soaps is $98 \%$. People belonging to different income levels use different brands, that fall under different market segments but in general all the income levels use the soap resulting in the second largest category in India. The rural consumers constitute $71 \%$ of the population. The remote and rural demand is growing, with many brands launched in the market. And moreover the Toilet soap industry is one of the oldest Fast Moving Consumer Goods (FMCG) industry in India. The soap market is one of the highest penetrated category within FMCG sector reaching an estimated 96\% urban and $88 \%$ of rural markets. It is also the industry which is characterized by a high level of intense competition. The various competitors in this sector ranges from MNC's like Unilever, Henkel, P\&G to local big companies like Wipro, Nirma and Godrej.

Within an array of products in various categories of soap markets HUL is the market leader in all category. There is paradigm shift taking place in the toilet soap market. The premium category and the popular category are the sectors which are experiencing high growth rate. The popular and economy segments account for about four-fifths of the entire market for soaps. The future growth of soap is in the premium category.

Many marketers are drawing different game plans to defend the competitors in the field.

The toilet soaps despite of their divergent brands are not well differentiated by the consumers. It is, therefore not clear if it is the brand loyalty or experimentation lured by the high volume media campaign, which sustain them. As a result of which the market had been fragmented. It is very clear that the toilet soap market once upon a time it is of only urban phenomenon but now it is penetrated even into rural markets also. The competition too had increased. The incremental demand flows from population increase and rise is in the consumption or usage practices impacted as it is by a greater concern for hygienic conditions. And moreover the increased sales revenues would also expand from up gradation of quality too.

The soap market can be divided into four price segments; premium, popular, discount and economy soaps. Approximately the premium soaps are estimated to have a market sales volume of nearly 90,000 tonnes. This conversion into a share of about 14 to $15 \%$ is roundabout as much as $30 \%$.

\section{Literature Review}

Early research on intergenerational consumption patterns ranged from behavior product choice in financial planning and to brand preference prediction and shopping strategy congruence between mothers and daughters. Guest's longitudinal study covering twenty years recognized the lifetime dimension of brand loyalty learned during childhood (1964, 1955). These studies demonstrate that preference was repeated generationally but do not address why. Similar research connects product preference to early family socialization and shows that parental influence wanes with age and fluctuations in income.

This research has traditionally taken two routes and is often a

*Corresponding author: Jakkireddy Suresh Reddy, Department of Management Studies, Rajeev Gandhi Memorial College of Engineering and Technology, Jawaharlal Nehru Technological University Anantapur, Andhra Pradesh State, India, Tel: +91 9866728854; E-mail: jakkireddysureshreddy@gmail.com

Received October 31, 2016; Accepted November 18, 2016; Published November 25, 2016

Citation: Reddy JS, Ramana KA, Bhandari M (2016) Statistical Analysis of the Core Determinants Influencing the Consumers Brand Preference in Generalization of Bath Soaps. J Account Mark 5: 201. doi:10.4172/2168-9601.1000201

Copyright: $\odot 2016$ Reddy JS, et al. This is an open-access article distributed unde the terms of the Creative Commons Attribution License, which permits unrestricted use, distribution, and reproduction in any medium, provided the original author and source are credited. 
combination of both. The first focuses on the importance of social agents; environmental and media factors in the social learning model and the second centers on children's developing psychology to process consumer information in the cognitive development approach. Brands used since childhood can become "friends" with whom relationships are fashioned early in our social lives.

There has been a long standing interest from marketers to understand how consumers form their preferences toward a specific brand. Brand preference is closely related to brand choice that can facilitate consumer decision making and activate brand purchase. Knowing the pattern of consumer preferences across the population is a critical input for designing and developing innovative marketing strategies. It also uncovers the heterogeneity of consumer choices leading to efficient market segmentation strategies.

Most of the studies have shown marketing mix factors have a relationship on the purchasing behavior of the consumer. The proper alignment of the marketing mix is essential in achieving the consumers mind share for the brand. Gupta [1] indicates that marketing mix have a strong relationship with consumers buying patterns, brand choices and incidences of purchase. The impact of demographical factors also plays a significant role in consumers buying behavior. Age group is an attribute which has a direct impact on person's attitude towards a brand. Based on the maturity the preference for toilet soap or any other product may vary. The education level of a person also influence in the decision making process. A well educated person may analyze the ingredients in particular beauty soap but less educated person may not, due to lack of knowledge. Income level of a person has a direct impact on the purchasing of a product. When the income levels rises naturally people tend to buy more luxury/premium products. The income affects the type of goods that consumers are likely to buy [2-6].

Consumer preferences are varied and are more regionally specific. India is divided into four regions: North, East, West, and South. Consumers in the North prefer pink colored soaps, which have floral profiles. Here the fragrance preference is for more sophisticated profiles reflecting their lifestyles. Freshness soaps with lime and citrus note are also popular preferences as the climate in the North is very hot and citrus/lime scented soaps are seen to be refreshing. The East is not a big soap market; hence no particular preference skews. Consumers in the West exhibit preferences for strong, impactful fragrances and somewhat harsher profiles compared to the North. Preferences are more for the pink soaps with floral fragrances, primarily rose, which are positioned on the beauty platform. In the South, the skew is towards specific soap segments $[7,8]$.

\section{Objectives of the Study}

To statistically analyze the core determinants influencing the consumer brand preference in generalization of bath soaps. It includes analyzing the core factors like education, age, income, price, advertisement, celebrity and product quality influencing the brand preference in generalization of bath soaps.

\section{Scope and Limitations of the Study}

The study was conducted in and around Nandyal town, Andhra Pradesh state, India.

It is believed that the findings in and around Nandyal town are fair representative of the other parts of the State and the lifestyle and other parameters are not much different from what exist in the area of survey [9].
Though the market has over hundred fifty toilet soap brands but only ten brands were chosen for the for the study of brand preference. Other limitations have been identified in this study are, the research work covers only the areas in and around Nandyal town, the sample size do not ensure representative and conclusive finding and finally, a more robust analysis is needed to reach a strong conclusion (Table 1).

\section{Research Methodology and Hypothesis}

The following research methodology was designed to study the determinants influencing consumer brand preference in generalization of bath soaps. This describes the education, age, income, price, advertisement, celebrity and product quality as independent variables and brand preference as dependent variable [10-15]

The present study was undertaken to study the brand preference towards toilet soaps. A descriptive research was carried out. A field survey was conducted in which a sample of 100 customer purchasing patterns of bath soaps were observed for about five months successively, (March to July, 2016) in and around Nandyal town of Kurnool district, the areas were selected conveniently. The consumers were selected randomly constituting sample size as 100 . Likert scale was used in the questionnaire, where One time purchase of same brand $=10$, Two times purchase of same brand $=20$, Three times purchase of same brand $=30$, Four times purchase of same brand $=40$, Five times purchase of same brand $=50$ and Six times purchase of same brand $=60$. In the case of Simple Linear Regression and Multiple regression a sample of 100 customers were observed for a period of four months [16-20]. The consumers were served with a structured schedule as data collection tool. The retailers also were questioned to gain new insights on buying behavior and brand preference. The data collected was analyzed mainly thorough descriptive statistics, using ANOVA-Two factor without replication to analyze the influence of education and age factors on brand preference, One way ANOVA to analyze the impact of income factor on brand preference, Simple linear regression analysis to analyze the impact of price on brand preference and Multiple linear regression analysis was used to analyze the impact of advertisement and celebrity on brand preference [21-24].

\section{Results, Discussion and Conclusion}

\section{Two Factor without replication used to analyze the influence of age and occupation on brand preference}

ANOVA with two factors Age (A Factor) Education (B Factor) each with five levels.

Hypothesis in Two Way ANOVA

$\mathrm{H}_{0} 1=\mu_{\mathrm{A} 1}=\mu_{\mathrm{A} 2}=\mu_{\mathrm{A} 3}=\mu_{\mathrm{A} 4}=\mu_{\mathrm{A} 5}$

$\mathrm{H}_{11}=$ Not all means are equal.

$\mathrm{H}_{0} 2=\mu_{\mathrm{B} 1}=\mu_{\mathrm{B} 2}=\mu_{\mathrm{B} 3}=\mu_{\mathrm{B} 4}=\mu_{\mathrm{B} 5}$

\begin{tabular}{|c|c|}
\hline Preferred Soap Brand & $\mathbf{( \% ) 1 0 0}$ \\
\hline Lux & 15 \\
\hline Dove & 25 \\
\hline Santoor & 12 \\
\hline Liril & 12 \\
\hline Dettol & 14 \\
\hline Lifebuoy & 10 \\
\hline Cinthol & 10 \\
\hline Medimix & 2 \\
\hline
\end{tabular}

Table 1: Classification based on preferred Soap brands of the 100-consumers. 
Citation: Reddy JS, Ramana KA, Bhandari M (2016) Statistical Analysis of the Core Determinants Influencing the Consumers Brand Preference in Generalization of Bath Soaps. J Account Mark 5: 201. doi:10.4172/2168-9601.1000201

Page 3 of 5

\section{$\mathrm{H}_{1} 2=$ Not all means are equal.}

Education and Age Factors influencing the Brand Preference

Education and Age are the two factors. Age factor is of five levels. Education is of six levels including others.

A sample of 100 customers purchasing patterns of bath soaps were observed for about five months successively [2]. Likert scale was used in the questionnaire, where One time purchase of same brand $=10$, Two times purchase of same (Tables 2-4).

\section{Statistical conclusion}

Since the calculated F value for the rows 3.795699>3.006917 F crit, the null hypothesis is rejected.

Therefore the education factor influences the brand preference. And the calculated F value for the columns $1.430108<3.006917 \mathrm{~F}$ crit, the null hypothesis is accepted.

Therefore the age factor does not influence the brand preference.

One way ANOVA - income factor on brand preference of different bath soaps

Likert scale was used in the questionnaire, where One time purchase of same brand $=10$, Two times purchase of same brand $=20$, Three times purchase of same brand $=30$, Four times purchase of same brand $=40$, Five times purchase of same brand $=50$, Six times purchase of same brand $=60$ and seven times purchase of same brand $=70$ (Table 5).

Hypothesis,

$\mathrm{H}_{0} 3=\mu_{1}=\mu_{2}=\mu_{3}=\mu_{4}=\mu_{5}$

$\mathrm{H}_{1} 3=$ Not all means are equal.

\begin{tabular}{|c|c|c|c|c|c|}
\hline & Up to 20 & $\mathbf{2 1 - 3 0}$ & $\mathbf{3 1 - 4 0}$ & $\mathbf{4 1 - 5 0}$ & $\mathbf{> 5 0}$ \\
\hline No Formal Education & 20 & 40 & 50 & 50 & 20 \\
\hline Higher Secondary & 30 & 10 & 20 & 40 & 30 \\
\hline Graduation & 10 & 30 & 60 & 30 & 60 \\
\hline Post Graduation & 60 & 40 & 60 & 50 & 40 \\
\hline Professional & 60 & 40 & 60 & 60 & 60 \\
\hline
\end{tabular}

Table 2: Education and Age Factors influencing the Brand Preference.

\begin{tabular}{|c|c|c|c|c|}
\hline Summary & Count & Sum & Average & Variance \\
\hline No Formal Education & 5 & 180 & 36 & 230 \\
\hline Higher Secondary & 5 & 130 & 26 & 130 \\
\hline Graduation & 5 & 190 & 38 & 470 \\
\hline Post Graduation & 5 & 250 & 50 & 100 \\
\hline Professional & 5 & 280 & 56 & 80 \\
\hline Up to 20 & 5 & 180 & 36 & 530 \\
\hline $21-30$ & 5 & 160 & 32 & 170 \\
\hline $31-40$ & 5 & 250 & 50 & 300 \\
\hline $41-50$ & 5 & 230 & 46 & 130 \\
\hline Above 50 & 5 & 210 & 42 & 320 \\
\hline
\end{tabular}

Table 3: Education and Age Factors influencing the Brand Preference.

\begin{tabular}{|c|c|c|c|c|c|c|}
\hline Source of variation & SS & df & MS & F & P-value & F crit \\
\hline Rows & 2824 & 4 & 706 & 3.795 & 0.02 & 3.006 \\
\hline Columns & 1064 & 4 & 266 & 1.430 & 0.27 & 3.006 \\
\hline Error & 2976 & 16 & 186 & & & \\
\hline Total & 6864 & 24 & & & & \\
\hline
\end{tabular}

Table 4: Education and Age Factors influencing the Brand Preference.

\section{Summary}

\section{Statistical conclusion}

Since the calculated F value $2.665228>2.246408 \mathrm{~F}$ crit, the null hypothesis is rejected. Therefore there is a significant statistical difference, concluding that the income factor influences the brand preference (Tables 6 and 7).

\section{Simple linear regression}

A sample of 100 customers were used in collecting the following data. Does the Price variable affects the Brand preference (Tables 8-12).

\begin{tabular}{|c|c|c|c|c|c|c|}
\hline $\begin{array}{c}\text { Wretched } \\
\text { (Less than } \\
1200 \text { Rs.) }\end{array}$ & $\begin{array}{c}\text { Poor Cls } \\
\text { (1200- } \\
2400 \text { Rs.) }\end{array}$ & $\begin{array}{l}\text { Lower } \\
\mathrm{Cl}(2400- \\
4000 \text { Rs.) }\end{array}$ & $\begin{array}{c}\text { Middle } \\
\mathrm{Cl}(4000- \\
12000 \\
\text { Rs. })\end{array}$ & $\begin{array}{c}\text { Upper } \\
\text { cls } \\
(12000- \\
48000 \\
\text { Rs.) }\end{array}$ & $\begin{array}{l}\text { Rich } \\
\text { Class } \\
(48000- \\
240000 \\
\text { Rs.) }\end{array}$ & $\begin{array}{c}\text { Super } \\
\text { Rich } \\
(240000- \\
\& \text { above })\end{array}$ \\
\hline 60 & 20 & 40 & 70 & 50 & 70 & 70 \\
\hline 30 & 60 & 40 & 60 & 50 & 70 & 50 \\
\hline 20 & 60 & 60 & 70 & 40 & 20 & 60 \\
\hline 10 & 60 & 40 & 60 & 10 & 60 & 40 \\
\hline 30 & 10 & 20 & 50 & 70 & 30 & 70 \\
\hline 40 & 40 & 50 & 60 & 50 & 10 & 50 \\
\hline 70 & 50 & 40 & 50 & 40 & 40 & 40 \\
\hline 50 & 60 & 50 & 60 & 70 & 50 & 50 \\
\hline 40 & 20 & 40 & 70 & 70 & 40 & 70 \\
\hline 30 & 40 & 40 & 60 & 30 & 60 & 60 \\
\hline
\end{tabular}

Table 5: One Way ANOVA - Income factor on Brand Preference of different bath soaps.

\begin{tabular}{|c|c|c|c|c|c|c|}
\hline Source of Variation & SS & df & MS & F & P-value & F crit \\
\hline Between Groups & 4117.14 & 6 & 686.19 & 2.665 & 0.022 & 2.246 \\
\hline Within Groups & 16220 & 63 & 257.46 & & & \\
\hline Total & 20337.1 & 69 & & & & \\
\hline
\end{tabular}

Table 6: ANOVA.

\begin{tabular}{|c|c|c|c|c|c|c|}
\hline Source of Variation & SS & df & MS & F & P-value & F crit \\
\hline Between Groups & 4117.14 & 6 & 686.19 & 2.665 & 0.022 & 2.246 \\
\hline Within Groups & 16220 & 63 & 257.46 & & & \\
\hline Total & 20337.1 & 69 & & & & \\
\hline
\end{tabular}

Table 7: ANOVA.

\begin{tabular}{|c|c|}
\hline Price ( Rs) of $\mathbf{1 2 5} \mathbf{g}$ Soap & No. of customers purchased \\
\hline 14 & 4 \\
\hline 20 & 19 \\
\hline 25 & 30 \\
\hline 29 & 23 \\
\hline 40 & 10 \\
\hline 42 & 4 \\
\hline 48 & 10 \\
\hline
\end{tabular}

Table 8: Simple Linear Regression: A sample of 100 Customers were used in collecting the following data. Does the Price variable affects the Brand preference.

\begin{tabular}{|c|c|}
\hline \multicolumn{2}{|c|}{ Regression Statistics } \\
\hline Multiple R & 0.28544 \\
\hline R Square & 0.08148 \\
\hline Adjusted R Square & -0.1022 \\
\hline Standard Error & 10.4410 \\
\hline Observations & 7 \\
\hline
\end{tabular}

Table 9: Summary Output. 
Citation: Reddy JS, Ramana KA, Bhandari M (2016) Statistical Analysis of the Core Determinants Influencing the Consumers Brand Preference in Generalization of Bath Soaps. J Account Mark 5: 201. doi:10.4172/2168-9601.1000201

Page 4 of 5

\section{Statistical conclusion}

The correlation coefficient is 0.28 , which signifies that there is weak relationship between the Price and Brand preference. The regression line doesn't fit the data properly. The significance F Value $0.5349>0.05$, concludes that there is no statistical significance of the independent variable price. Even most of the residual outputs are negative showing that there is wide deviation between the actual and predicted values.

\section{Multiple regression analysis}

Samples of 100 customers were chosen and their purchasing patterns were recorded for a period of four months as below (Tables 13-15).

\section{Statistical conclusion}

The correlation coefficient 0.755 signifies that the relation between the independent variables and dependent variable is weak.

\begin{tabular}{|c|c|c|c|c|c|}
\hline & df & SS & MS & F & Significance F \\
\hline Regression & 1 & 48.350 & 48.3504 & 0.4435 & 0.5349 \\
\hline Residual & 5 & 545.078 & 109.016 & & \\
\hline Total & 6 & 593.429 & & & \\
\hline
\end{tabular}

Table 10: ANOVA.

\begin{tabular}{|c|c|c|c|c|}
\hline & Coefficients & Standard Error & t Stat & P-value \\
\hline Intercept & 21.3456 & 11.312 & 1.887 & 0.1178 \\
\hline Price (Rs) of 125 g Saop & -0.2267 & 0.3404 & -0.666 & 0.5349 \\
\hline
\end{tabular}

Table 11: ANOVA.

\begin{tabular}{|c|c|c|}
\hline Observation & Predicted No. of customers purchased & Residuals \\
\hline 1 & 18.1719 & -14.1719 \\
\hline 2 & 16.8117 & 2.1883 \\
\hline 3 & 15.6783 & 14.3217 \\
\hline 4 & 14.7715 & 8.2285 \\
\hline 5 & 12.2779 & -2.2779 \\
\hline 6 & 11.8245 & -7.8245 \\
\hline 7 & 10.4643 & -0.4643 \\
\hline
\end{tabular}

Table 12: Residual Output.

\begin{tabular}{|c|c|c|}
\hline $\begin{array}{c}\text { No. of Customers } \\
\text { purchased a specific } \\
\text { brand }\end{array}$ & $\begin{array}{c}\text { No. of times the Ad } \\
\text { repeated in a period of } \\
\text { four months }\end{array}$ & $\begin{array}{c}\text { No. of times the same } \\
\text { celebrity endorsed the brand } \\
\text { during the four months }\end{array}$ \\
\hline 10 & 58 & 42 \\
\hline 8 & 63 & 63 \\
\hline 10 & 32 & 28 \\
\hline 14 & 52 & 50 \\
\hline 20 & 86 & 80 \\
\hline 15 & 79 & 68 \\
\hline 15 & 88 & 59 \\
\hline 8 & 21 & 16 \\
\hline
\end{tabular}

Table 13: Multiple Regression Analysis-A sample of 100 customers were chosen $\&$ their purchasing patterns were recorded for a period of four months as below.

\begin{tabular}{|c|c|}
\hline Regression Statistics & \\
\hline Multiple R & 0.75543 \\
\hline R Square & 0.57068 \\
\hline Adjusted R Square & 0.39895 \\
\hline Standard Error & 3.26301 \\
\hline Observations & 8 \\
\hline
\end{tabular}

Table 14: Summary Output.
The coefficient of determination 0.57, i.e., the independent variables Advertising and Celebrity explains only 0.57 of variability of dependent variable, no. of customers purchased. Unstandardized coefficients indicate how much the dependent variable varies with an independent variable, when all other independent variables are held constant. In this case the unstandardized coefficient No. of times the Ad repeated in a period of four months I equal to 0.075 , this means that for every repetition of the Ad, there is an increase of no. of customers purchased by 0.0751 , means very less influence of the no. of times the Ad repeated over the brand preference. And this is similar case with the other unstandardized coefficient celebrity. The two independent variables didn't add statistically significantly to the prediction.

\section{Z-Test used to find whether the quality factor influences the brand preference of the customers}

A sample of 100 was taken and divided them into 10 groups of ten each. The collected data is tabulated (Tables 16 and 17).

Hypothesis,

$\mathrm{H} 0 ; \mu=10$,

$\mathrm{H} 1 ; \mu \neq 10$,

Significance Level $(\alpha)=0.05$,

Mean of 100 Customers in case of all customers prefer the same brand $=10(\mu)$,

Where $\mu=$ Population mean $=10$,

Population standard deviation=Not known,

Standard error of mean $=\frac{\text { sample standard deviation }}{\text { Sqrt. of sample size }}$

$=0.233$

Sample Mean=6.1,

Sample standard deviation $=2.33$.

$Z=\frac{\text { Sample mean }- \text { Population mean }}{\text { Standard error of mean }}$

$=-16.7381$.

\begin{tabular}{|c|c|c|c|c|}
\hline & Coefficients & Standard Error & t Stat & P-value \\
\hline Intercept & 4.664 & 3.253 & 1.434 & 0.211 \\
\hline No. of times the Ad repeated & 0.075 & 0.131 & 0.574 & 0.591 \\
\hline $\begin{array}{c}\text { No. of times the same celebrity } \\
\text { endorsed }\end{array}$ & 0.066 & 0.151 & 0.436 & 0.681 \\
\hline
\end{tabular}

\begin{tabular}{|c|c|}
\hline Group & No. of customers preferring the same brand because of Good quality \\
\hline 1 & 6 \\
\hline 2 & 5 \\
\hline 3 & 9 \\
\hline 4 & 4 \\
\hline 5 & 3 \\
\hline 6 & 5 \\
\hline 7 & 4 \\
\hline 8 & 7 \\
\hline 9 & 10 \\
\hline 10 & 8 \\
\hline
\end{tabular}

Table 16: Z-Test used to find whether the quality factor influences the brand preference of the customers. 
Citation: Reddy JS, Ramana KA, Bhandari M (2016) Statistical Analysis of the Core Determinants Influencing the Consumers Brand Preference in Generalization of Bath Soaps. J Account Mark 5: 201. doi:10.4172/2168-9601.1000201

\begin{tabular}{|c|c|c|}
\hline \multicolumn{3}{|c|}{ Significance Range } \\
\hline 0.522246836 & to & -0.5222468 \\
\hline
\end{tabular}

Table 17: Significance Range.

\section{Statistical conclusion}

Since the $\mathrm{z}$ score $-16.738<0.522$ and $-16.738<-0.5222$, the Null Hypothesis is rejected and therefore there is statistical significance between Quality and Brand preference. And we can conclude that product quality affects the brand preference.

\section{References}

1. Gupta S (1988) Impact of sales promotion when, what and how much to buy. Journal of Marketing Research 25: 1988.

2. Baltas G, Argouslidis PC (2007) Consumer characteristics and demand for store brands. Int J. Ret \& Dist Manage 35: 328-341.

3. Brown WF (1950) The Determination of Factors Influencing Brand Choice. The Journal of Marketing 14: 699 -706.

4. Dinlersoz EM, Pereira $P$ (2007) On the diffusion of electronic commerce. Int $\mathrm{J}$ Ind Org 25: 541-574.

5. Henry A (2001) Consumer Behavi--our \& Marketing Action-Thomson Learning.

6. Gensch DH (1987) A two-stage disaggregate attribute choice model. Mark Sci 6: 223-231.

7. Heding T, Knudtzen F, Bjerre M (2009) Brand Management, Research. Theory and Practice, Routledge.

8. Keller KL (1998) Strategic Brand Management: Building, Measuring, And Managing Brand Equity. Prentice Hall, Upper Saddle River, New Jersey.

9. Modahl M (2000) Now or Never: How Companies Must Change to Win the Battle for the Internet Consumer. Harper Business: New York.

10. Nataraj S, Nagaraja N (2012) Customer Satisfaction in Automobile Industry - An Indian Online Buyers Perspective of Car Manufacturers "Websites". International Journal of Multidisciplinary Research 2: 92-107.
11. Niedrich RW, Swain SD (2003) The influence of pioneer status and experience order on consumer brand preference: A mediated-effects model. Journal of the Academy of Marketing Science 31: 468-480.

12. Perez ME, Padgett D, Burgers $W$ (2011) Intergenerational influence on brand preferences. Journal of Product \& Brand Management 20: 5-13.

13. Pras B, Summers JO (1978) Perceived risk and composition mo-dels for multiattribute decisions. Journal of Marketing Research 15: 429-437.

14. Ramesh S (2012) Brand Preference of Passenger Cars in Aurangabad District. International Journal of Multidisciplinary Research 2: 431-442.

15. Ross I (1971) Self-concept and brand preference. Journal of Business 44: 38-50.

16. Russell GJ, Kamakura WA (1997) Modeling multiple category brand preference with household basket data. Journal of Retailing 73: 439-46.

17. Schlosser AE (2003a) Experiencing products in the virtual world: the role of goal and imagery in influencing attitudes. Journal of Consumer Research 30: 184-198.

18. Sheth JN (1968) How adults learn brand preferences. Journal of Advertising Research 8: 25-36.

19. Singh J, Ehrenberg A, Goodhardt G (2008) Measuring customer loyalty to product variants. Int. J. Mark Res 50: 513-530.

20. Sriram S, Chintagunta PK, Neelamegham R (2006) Effects of brand preference, product attributes, and marketing mix variables on technology product markets. Marketing Science 25: 440-456.

21. Stafford JE (1966) Effects of group influences on consumer brand preferences. Journal of Marketing 3: 68-75.

22. Von Wallpach S, Kreuzer M (2012) Multi-sensory sculpting (MSS): Eliciting embodied brand knowledge via multisensory metaphors. Journal of Business Research.

23. Zajonc RB, Markus H (1982) Affective and cognitive factors in preferences. Journal of Consumer Research 9: 123.

24. Zentes J, Morschett D, Schramm-Klein H (2008) Brand personality of retailers - an analysis of its applicability and its effect on store loyalty. International Review of Retail, Distribution \& Consumer Research 18: 167-184. 